\title{
Taxonomical, Phytochemical, Traditional Explanation, Nutritional Values, and Biological Activities of Certain Edible Medicinal Plants of Tripura, India
}

\author{
Bikash Debnath, Waikhom Somraj Singh, Sanchari Goswami and Kuntal Manna* \\ Natural cum Advance Synthetic Lab, Department of Pharmacy, Tripura University (A Central University), \\ Suryamaninagar - 799022, Agartala, India; k_manna2002@yahoo.com
}

\begin{abstract}
Edible plants are used as valuable sources of food and medicine to prevent nutritional imbalance, illness, and maintenance of human health. This review covers botanical descriptions, phytochemicals studies, traditional comprehensions, dietary values, and biological activities of ten vegetable plants and eight fruit plants of Tripura, India. The book "The Flora of Tripura State" helps to choose the plant species of Tripura, India and PubMed, NCBI, Google scholar databases have been used to describe the plant species briefly. Literature reveals that all the selected edible plants contain bio-active constituents (alkaloids, phenols, flavonoids, tannins, terpenoids, glycosides, etc.) and give dynamic biological activities. All the plants have a high nutritional value. This review believes it will provide significant advances in the prevention of malnutrition and chronic diseases.
\end{abstract}

Keywords: Biological Activities, Edible Medicinal Plants, Nutritional Values, Phytochemicals, Tripura

\section{Introduction}

Edible plants are essential in our diet and have ethnomedicinal values without any toxicity. They are the primary sources of food and highly beneficial for the nourishment of health and the prevention of diseases ${ }^{1}$. Terpenoids, limonoids, phytoestrogens, carotenoids, polyphenols, glucosinolates, flavonoids, isoflavonoids, and anthocyanidins are active phytochemicals present in fruits, seeds, herbs, and vegetables. In different stages of life cycles, these phytochemicals provide various health beneficial activities ${ }^{2,3}$. Edible plants provide energy, proteins, necessary fats, vitamins, and minerals, to develop and for proper functions of life. A large variety of nutrients is essential for our daily diet for well-being. The pleasure of a healthy diet can also be one of the unique ethnic preferences of life. Concerns protein malnutrition is a paramount general health issue in emerging countries. Essential nutrients being roots and tubers are mostly stiff.
Nutritive fiber shows a dynamic role in diminishing the hazards of various illnesses ${ }^{4}$.

The Himalayas extends over eight Northeast states (Arunachal Pradesh, Assam, Manipur, Meghalaya, Mizoram, Nagaland, Sikkim, and Tripura) of India. It comprises over $16 \%$ of the country's geographical area. Tripura lies between $22^{\circ} 56^{\prime}-24^{\circ} 32^{\prime} \mathrm{N}$ latitudes and $90^{\circ} 09^{\prime}-92^{\circ} 20^{\prime} \mathrm{E}$ longitudes. The average temperature of Tripura is $27^{\circ} \mathrm{C}$ during summer and $8^{\circ} \mathrm{C}$ during winter. The average rainfall is about $2400 \mathrm{~mm}$. Although the biodynamic geographical diversity of Tripura, many bioactive plants are grown naturally. Some of these plant parts consumed directly by local peoples for their dietary benefits because these edible plants cannot produce toxic effects on human body ${ }^{5,6}$. This review covers general descriptions of plant, phytochemicals study, traditional comprehension, nutritional values, and biological activities of eighteen edible plants of Tripura, Northeast India.

\section{${ }^{*}$ Author for correspondence}




\section{Method for Plant Choosing and Elaboration}

The plant species of Tripura, India have been chosen from the book "The Flora of Tripura State"7. The selected is based on two categories i) vegetable plants and ii) fruit plants. PubMed, NCBI, Google scholar databases have been used to describe the chosen plant species.

\section{Vegetable Group's Plants}

\subsection{Elephant Foot Yam (Amorphophallus paeoniifolius)}

Amorphophallus paeoniifolius (Figure 1A) is a stout herbaceous plant well known as elephant foot yam. It is a potential humid tuber crop of the Araceae family that widely grows in a shady region or swampy areas of northeast India during June-August. A darkbrown corn is an edible part ${ }^{8}$. The taxonomical classification of Amorphophallus paeoniifolius is represented in Table 1.

Table 1. Taxonomical classification of Amorphophallus paeoniifolius

\begin{tabular}{|c|c|}
\hline Kingdom & Plantea \\
\hline Phylum & Tracheophyta \\
\hline Class & Liliopsida \\
\hline Order & Arales \\
\hline Family & Araceae \\
\hline Genus & Amorphophallus \\
\hline Species & A. Paeoniifolius \\
\hline
\end{tabular}

Qualitative analysis of the methanolic extract and 70\% of hydro-alcoholic extract of corm of Amorphophallus paeoniifolius have shown the presence of alkaloids, steroids, flavonoids, and phenols. Traditionally corms are used as an astringent, liver tonic, thermogenic, irritation, painkiller, anti-inflammatory, anti-haemorrhoidal, hemostatic, linctus, relieve flatulence, stimulate appetite, anthelmintic, aphrodisiac, emmenagogue, rejuvenating tonic ${ }^{8}$. The corm of Amorphophallus paeoniifolius is highly nutritional food. Nutritional values per $100 \mathrm{~g}$ of corm consists $11.53 \mathrm{~g}$ protein, $3.52 \mathrm{~g}$ fat, $70.75 \mathrm{~g}$ carbohydrate, $14.32 \mathrm{~g}$ crude fiber, $359.08 \mathrm{Kcal}$ energy, $3.81 \mathrm{mg}$ potassium, $11.92 \mathrm{mg}$ magnesium, $2.31 \mathrm{mg}$ Zinc, and $34.02 \mathrm{mg}$ iron respectively ${ }^{9}$. Different solvents extract (petroleum ether, methanolic extract, chloroform extract, pet-ether extract) of Amorphophallus paeoniifolius have shown analgesic, anti-inflammatory, CNS depressant, antimicrobial, anthelmintic, hepatoprotective, antioxidant, and antitumor activities ${ }^{8}$.

\subsection{Taro (Colocasia esculenta)}

Colocasia esculenta (Figure 1B)is a tropical herbaceous perennial plant belonging to Araceae. It is cultivated primarily during the rainy season for its edible corms, most commonly known as taro, and other consumable parts are leaf and stem. It is believed to be one of the earliest cultivated plants. This plant is found in entire northeastern India. Taxonomical classification of Colocasia esculenta is represented in Table $2^{10}$.

Table 2. Taxonomical classification of Colocasia esculenta

\begin{tabular}{|c|c|}
\hline Kingdom & Plantae \\
\hline Phylum & Tracheophyta \\
\hline Class & Liliopsida \\
\hline Order & Arales \\
\hline Family & Araceae \\
\hline Genus & Colocasia \\
\hline Species & C. esculenta \\
\hline
\end{tabular}

Phytochemicals estimate different edible parts (leaf, stem, and taro) of Colocasia esculenta have shown the presence of phenols, flavonoids, terpenoids, and steroids ${ }^{11-13}$. The documented record of ethnobotanists, various edible parts of Colocasia esculenta, is used to diminish the menace of obesity, heart attack, diabetes, and iron level maintenance $^{14}$. Nutritional values per $100 \mathrm{~g}$ of corm consist of $2.5 \mathrm{~g}$ protein, $0.2 \mathrm{~g}$ fat, $19 \mathrm{~g}$ carbohydrate, $3.4 \mathrm{~g}$ crude fiber, $85 \mathrm{Kcal}$ energy, $32 \mathrm{mg}$ calcium, $64 \mathrm{mg}$ phosphorus, $514 \mathrm{mg}$, potassium, $7 \mathrm{mg}$ sodium, and 0.8 $\mathrm{mg}$ iron, and $10 \mathrm{mg}$ Vit. C respectively. Nutritional values per $100 \mathrm{~g}$ of the leaf consist of $4.4 \mathrm{~g}$ protein, $1.8 \mathrm{~g}$ fat, 12.2 g carbohydrate, $0.6 \mathrm{~g}$ crude fiber, $69 \mathrm{Kcal}$ energy, $268 \mathrm{mg}$ calcium, $78 \mathrm{mg}$ phosphorus, $1237 \mathrm{mg}$, potassium, $11 \mathrm{mg}$ sodium, and $4.3 \mathrm{mg}$ iron, $20385 \mathrm{IU}$ Vit. A and $142 \mathrm{mg}$ Vit. C respectively ${ }^{15}$. Corm and leaf of Colocasia esculenta possess anti-microbial, anti-oxidant, and anti-diabetic activities $^{16-18}$.

\subsection{Bengal Arum (Typhonium trilobatum)}

Typhonium trilobatum (Figure 1C) is a leafy vegetable evergreen perennial herb of height $0.85 \mathrm{~m}$ tall. This herb mainly grows between May to July on plain grassland. Taxonomical classification of Typhonium trilobatum is represented in Table $3^{1}$. 
Table 3. Taxonomical classification of Typhonium trilobatum

\begin{tabular}{|c|c|}
\hline Kingdom & Plantae \\
\hline Phylum & Tracheophyta \\
\hline Class & Liliopsida \\
\hline Order & Alismatales \\
\hline Family & Araceae \\
\hline Genus & Typhonium \\
\hline Species & T. trilobatum \\
\hline
\end{tabular}

Typhonium trilobatum contains alkaloids, phenols, flavonoids, and steroids. Beta-sitosterol is one of the essential sterols isolated from Typhonium trilobatum ${ }^{1,19}$. In India, China, Bangladesh, leaves and tubers are consumed as food and frequently prescribed to the patient suffering from piles, rheumatism, constipation, hemorrhoids, trauma, and injuryl.Nutritional values per $100 \mathrm{~g}$ of the leaf consist of $2.81 \mathrm{~g}$ protein, $0.66 \mathrm{~g}$ fat, $2.94 \mathrm{~g}$ carbohydrate, $2.44 \mathrm{~g}$ crude fiber, $28.94 \mathrm{Kcal}$ energy, 22.59 $\mathrm{mg}$ calcium, $0.03 \mathrm{mg}$ sodium, and $58.40 \mathrm{mg}$ iron, and $108.08 \mathrm{mg}$ Vit. C respectively ${ }^{20}$. Typhonium trilobatum has multiple pharmacological activities, including antiinflammatory, analgesic, wound healing, anti-bacterial, anti-fungal, anti-diarrheal, larvicidal, anti-oxidant, antidiabetic and anti-depressant ${ }^{1}$.

\subsection{Dolichos Bean (Lablab purpureus)}

Lablab purpureus (Figure 1D) is generally known as Dolichos bean, Hyacinth bean, or Field bean. It exists only as a whole antique food amongst cultivated plants. It is a bushy, semi-erect, perennial herb, having no affinity to ascend. This plant grows during the winter season. Taxonomical classification of Lablab purpureus is represented in Table $4^{21}$.

Table 4. Taxonomical classification of Lablab purpureus

\begin{tabular}{|c|c|}
\hline Kingdom & Plantae \\
\hline Phylum & Tracheophyta \\
\hline Class & Magnoliopsida \\
\hline Order & Fabales \\
\hline Family & Fabaceae \\
\hline Genus & Lablab \\
\hline Species & L.purpureus \\
\hline
\end{tabular}

The mature seeds of Lablab purpureus contained cyanogenic glycosides, oxalates, phytates, tannins and saponins. Seeds were used to stimulate stomach, treatment of cholera, diarrhea, colic, rheumatism, and sunstroke ${ }^{22}$. Seeds of Lablab purpureus contain high nutritional values. In $100 \mathrm{~g}$ of fresh seeds gives $23.90 \mathrm{~g}$ of protein, $1.69 \mathrm{~g}$ of fat, $60.74 \mathrm{~g}$ of carbohydrate, and 344 Kcal of total energy. Grains also contain the right amount of minerals such as $1235 \mathrm{mg}$ potassium, $21 \mathrm{mg}$ sodium, $1.335 \mathrm{mg}$ copper, $130 \mathrm{mg}$ calcium, $283 \mathrm{mg}$ Magnesium, and $5.10 \mathrm{mg}$ iron in $100 \mathrm{~g}$ of sample. Niacin (1.610 $\mathrm{mg} / 100 \mathrm{~g})$ and thiamin $(1.130 \mathrm{mg} / 100 \mathrm{~g})$ are two essential vitamins present in seeds ${ }^{23}$. Seeds of Lablab purpureus possess anti-inflammatory, antioxidant, antibacterial and cytotoxicity activities Seeds of Lablab purpureus shows anti-inflammatory, antioxidant, antibacterial and cytotoxicity activities ${ }^{24}$.

\subsection{Clumping Bamboo (Melocanna baccifera)}

Melocanna baccifera (Figure 1E), an evergreen arborescent, non-clump forming, is a single bamboo species naturally distributed in a hilly area of northeast India like Tripura, Assam, and Meghalaya. Its local Bengali name is "Muli", and its English name is "Clumping bamboo". Edible parts are young shoots and are harvested during the rainy season. Culms are considered mature when it is two years old. Taxonomical classification of Melocanna baccifera is represented in Table $5^{25}$.

Table 5. Taxonomical classification of Melocanna baccifera

\begin{tabular}{|c|c|}
\hline Kingdom & Plantae \\
\hline Phylum & Tracheophyta \\
\hline Class & Liliopsida \\
\hline Order & Poales \\
\hline Family & Poaceae \\
\hline Genus & Melocanna \\
\hline Species & M. baccifera \\
\hline
\end{tabular}

4-Oxabicyclo[3.2.2]nona-1(7), 5, 8-triene, and verbacine are the two important phytochemicals present in the leaves and fruits of Melocanna baccifera. Fruit also contains ferulic acid as a phenolic compound ${ }^{26}$. The record of ethnobotanist, peoples of northeast India consumes the young shoots of Melocanna baccifera ${ }^{27}$. Per 100 gram of young shoot of Melocanna baccifera contained $43.35 \mathrm{~g}$ carbohydrate, $3.9 \mathrm{~g}$ protein, $1.77 \mathrm{~g}$ fat, and $204.93 \mathrm{kcal}$ energy. Shoot of Melocanna baccifera possess anti-oxidant activities ${ }^{28}$. 


\subsection{Miracle Tree (Moringa oleifera)}

Moringa oleifera (Figure 1F) native to northeast India grows in the tropical and subtropical part of lower Himalayan regions. It is a small, elegant, broadleaf tree with sparse foliage. The flowering period starts in January and lasts over March. The leaves, flowers, and immature pods (called long green pods), are eatable portions. Moringa oleifera, is also known as 'the miracle tree' due to its remarkable curing abilities for many chronic diseases. The taxonomical classification of Moringa oleifera is described in Table 629.

Table 6. Taxonomical classification of Moringa oleifera

\begin{tabular}{|c|c|}
\hline Kingdom & Plantae \\
\hline Phylum & Tracheophyta \\
\hline Class & Magnoliopsida \\
\hline Order & Capparales \\
\hline Family & Moringaceae \\
\hline Genus & Moringa \\
\hline Species & M. oleifera \\
\hline
\end{tabular}

Different edible parts of Moringa oleifera contained alkaloids, phenols, flavonoids, and saponines. Moringa oleifera leaves are used to reduce cholesterol and body weight, infertility in women, lower blood pressure, reduce jaundice, menstrual relief, cure diabetes, and constipation. Flowers were used to curing thyroid problems; roots were used to minimize spinal cord pain; seeds powder was used to kill intestinal worms, and pods were used to lower blood sugar levels ${ }^{30}$. The three common edible parts (leaves, flowers, and long green pods) of Moringa oleifera contained the right amounts of nutritional compositions. Nutritional values per $100 \mathrm{~g}$ of leaves consist of $6.7 \mathrm{~g}$ protein, $1.7 \mathrm{~g}$ fat, $12.5 \mathrm{~g}$ carbohydrate, $0.9 \mathrm{~g}$ crude fiber, $92 \mathrm{Kcal}$ energy, $259 \mathrm{mg}$ potassium, 70mg phosphorus, $440 \mathrm{mg}$ calcium, $0.85 \mathrm{mg}$ iron, $220 \mathrm{mg}$ of Vit. C and $300 \mathrm{IU}$ Vit. A. Nutritional values per $100 \mathrm{~g}$ of flowers consists $0.42 \mathrm{~g}$ protein, $0.88 \mathrm{~g}$ fat, $0.67 \mathrm{~g}$ carbohydrate, $0.14 \mathrm{~g}$ crude fiber, $17.95 \mathrm{Kcal}$ energy, $671 \mathrm{mg}$ potassium, $19.66 \mathrm{mg}$ phosphorus, $32.34 \mathrm{mg}$ calcium, $48.11 \mathrm{mg}$ iron, $7.6 \mathrm{mg}$ of Vit. C and $333 \mathrm{IU}$ Vit. A. Nutritional contents per $100 \mathrm{~g}$ of long green pods consists $2.5 \mathrm{~g}$ protein, 0.1 $\mathrm{g}$ fat, $3.7 \mathrm{~g}$ carbohydrate, $4.8 \mathrm{~g}$ crude fiber, $26 \mathrm{Kcal}$ energy, $259 \mathrm{mg}$ potassium, $110 \mathrm{mg}$ phosphorus, $30 \mathrm{mg}$ calcium, $5.3 \mathrm{mg}$ iron, $120 \mathrm{mg}$ of Vit. C and 184 IU Vit. $\mathrm{A}^{31}$. Different edible parts of Moringa oleifera possess hypolipidemic, anti-peroxidative, cardioprotective, antioxidant, anti-inflammatory, anti-nociceptive, anti-microbial, hepatoprotective, anti-hyperglycemic, down-regulation of nuclear factor-kappa B and anti-atherosclerotic activities ${ }^{29}$.

\subsection{Turkey Berry (Solanum torvum)}

Solanum torvum (Figure 1G) commonly known as Turkey berry. It is a bushy, erect, and spiny perennial plant. The fruit is the edible part of this plant. The flowering season of this plant is from May to July. The taxonomical classification of Solanum torvum is described in Table $7^{32}$.

Table 7. Taxonomical classification of Solanum torvum

\begin{tabular}{|c|c|}
\hline Kingdom & Plantae \\
\hline Phylum & Tracheophyta \\
\hline Class & Magnoliopsida \\
\hline Order & Solanales \\
\hline Family & Solanaceae \\
\hline Genus & Solanum \\
\hline Species & S. torvum \\
\hline
\end{tabular}

Sun-dried S. torvum fruits contain alkaloids, flavonoids, saponins, tannins, glycosides, and fixed oils. Others phytochemicals present in S.torvum is neochlorogenin 6-O- $\beta$ - $\mathrm{D}$-quinovo-pyranoside, neochlorogenin 6-O- $\beta$-D-xylopyranosyl- $(1 \rightarrow 3)-\beta$ D-quinovopyranoside, neochlorogenin 6-O $\alpha$-Lrhamnopyranosyl-( $1 \rightarrow 3)$ - $\beta$-Dquinovopyranoside, sola-genin $6-\mathrm{O}-\beta$-Dquinovopyranoside, solagenin $6-\mathrm{O}-\alpha-$ L-rhamnopyranosyl- $(1 \rightarrow 3)-\beta$ - $D$-quinovopyranoside, isoquercetin, rutin, kaempferol and quercetin. Traditionally it is used to control bacterial and fungal diseases $^{32}$. Nutritional values per $100 \mathrm{~g}$ fruits of Solanum torvum consists $2.32 \mathrm{~g}$ protein, $0.28 \mathrm{~g}$ fat, $7.04 \mathrm{~g}$ carbohydrate, $3.99 \mathrm{~g}$ crude fiber, $39.96 \mathrm{Kcal}$ energy, 21.5 mg zinc, $2.6 \mathrm{mg}$ copper, $19.5 \mathrm{mg}$ magnesium, $211.6 \mathrm{mg}$ calcium, and $76.9 \mathrm{mg}$ iron, and $2.68 \mathrm{mg}$ Vit. $\mathrm{C}^{33}$. Biological activities of the fruit of $\mathrm{S}$. torvum are anti-oxidant, anti-fungal, anti-bacterial, anti-ulcer, antihypertensive and metabolic correction, nephron-protective, cardioprotective, and anti-diabetic ${ }^{32}$.

\subsection{Sesame (Sesamum indicum)}

Sesame (Sesamum indicum) (Figure 1H) is an herbaceous annual plant. The primary flowering season is in July month. Oilseeds of sesame are traditional healthy food, generally used to improve nutritional status. The taxonomical classification of Sesamum indicum is represented in Table $8^{34}$. 
Table 8. Taxonomical classification of Sesamum indicum

\begin{tabular}{|c|c|}
\hline Kingdom & Plantae \\
\hline Phylum & Tracheophyta \\
\hline Class & Dicotyledonae \\
\hline Order & Scrophulariales \\
\hline Family & Padaliaceae \\
\hline Genus & Sesamum \\
\hline Species & S. Indicum \\
\hline
\end{tabular}

Sesamum indicum seed contains alkaloids, phenols, flavonoids, saponins, anthraquinones, terpenoids, and steroids. Traditionally the seed oil is used in cookery, as a stimulant, nutrient, aphrodisiac, diuretic, and in the remedy of dry cough, asthma, lung diseases, inflammation, ulcers, urinary diseases, and migraine ${ }^{34}$. Nutritional values per $100 \mathrm{~g}$ of seeds consists $17.73 \mathrm{~g}$ protein, $49.67 \mathrm{~g}$ fat, $23.45 \mathrm{~g}$ carbohydrate, $11.8 \mathrm{~g}$ crude fiber, $573 \mathrm{Kcal}$ energy, $7.75 \mathrm{mg}$ zinc, $468 \mathrm{mg}$ potassium, $4.08 \mathrm{mg}$ copper, $11 \mathrm{mg}$ sodium, $975 \mathrm{mg}$ calcium, $2.46 \mathrm{mg}$ magnesium, and 14.55 $\mathrm{mg}$ iron, $4.51 \mathrm{mg}$ niacin, $0.79 \mathrm{mg}$ thiamine, $9 \mathrm{IU}$ Vit. A and $0.25 \mathrm{mg}$ Vit. $\mathrm{E}^{35}$. Biological activities of Sesamum indicum seed oil regulate cholesterol, neurological role, and blood pressure. It also possesses antioxidant properties, and it is used for the protection from ultraviolet light ${ }^{36}$.

\subsection{Vegetable Hummingbird (Sesbania grandiflora)}

Sesbania grandiflora (Figure 1I) is a fast-growing perennial, deciduous, or evergreen legume tree that raises to $8-15 \mathrm{~m}$ high and $25-30 \mathrm{~cm}$ in diameter. The roots of the tree are usually heavily nodulated with large nodules. Leaves and white-yellowish color flowers are the edible portions. This plant is widespread in most humid tropical regions of Northeast India. The taxonomical classification of Sesbania grandiflora is represented in Table $9^{37}$.

Table 9. Taxonomical classification of Sesbenia grandiflora

\begin{tabular}{|c|c|}
\hline Kingdom & Plantae \\
\hline Phylum & Tracheophyta \\
\hline Class & Monoliopsida \\
\hline Order & Fabales \\
\hline Family & Fabaceae \\
\hline Genus & Sesbania \\
\hline Species & S. grandiflora \\
\hline
\end{tabular}

Leaves of Sesbania grandiflora contain alkaloids, flavonoids, glycosides, tannin, anthraquinone, steroid, and terpenoid ${ }^{38}$. Traditionally the mixture of fresh leaves juices and coconut milk is used topically for skin diseases $^{39} .100 \mathrm{~g}$ of fresh leaves contain $8 \mathrm{~g}$ protein, $1 \mathrm{~g}$ fat, $12 \mathrm{~g}$ carbohydrate, $2 \mathrm{~g}$ crude fiber, and $93 \mathrm{kcal}$ energy. The same quantity of leaves contains $1130 \mathrm{mg}$ calcium, $80 \mathrm{mg}$ phosphorus, and $4 \mathrm{mg}$ iron. $100 \mathrm{~g}$ of the fresh flower contains a size of $1.28 \mathrm{~g}$ protein, a size of $0.04 \mathrm{~g}$ fat, $6.73 \mathrm{~g}$ carbohydrate, and $27 \mathrm{kcal}$ energy. $100 \mathrm{~g}$ of flowers contains $18 \mathrm{mg}$ calcium, $84 \mathrm{~g}$ iron, $12 \mathrm{mg}$ magnesium, 30 mg phosphorus, $184 \mathrm{mg}$ potassium, $15 \mathrm{mg}$ sodium, $73 \mathrm{mg}$ Vitamin C, $0.083 \mathrm{mg}$ thiamine, and $0.081 \mathrm{mg}$ riboflavin ${ }^{40}$. Leaves and flower of Sesbania grandiflora give antimicrobial activity, decreased serum cholesterol levels, wound healing activity, and anti-ulcer activity ${ }^{41}$.

\subsection{Stink Bean (Parkia speciosa)}

Parkia speciosa (Figure 1J) or stink bean is a plant that is abundantly found in the tropical regions of lower parts of the Himalaya. Up to $15-40 \mathrm{~m}$ tall and $50-100 \mathrm{~cm}$ in diameter. Leaves are bipinnate, 2-6 cm elongated stems with the gland of 7-15 mm aloft stalk base. Pods are bulky, $35-55 \mathrm{~cm}$ in length and $3-5 \mathrm{~cm}$ broad. Seeds are the edible parts of this plant. Taxonomical classification of Parkia speciosa is described in Table $10^{42}$.

Table 10. Taxonomical classification of Parkia speciosa

\begin{tabular}{|c|c|}
\hline Kingdom & Plantae \\
\hline Phylum & Tracheophyta \\
\hline Class & Magnoliopsida \\
\hline Order & Fabales \\
\hline Family & Fabaceae \\
\hline Genus & Parkia \\
\hline Species & P. speciosa \\
\hline
\end{tabular}

Seeds of Parkia speciosa consist of alkaloid, terpenoid, phenolic, flavonoid, and tannin. In the seeds, identified terpenoid was $\beta$-sitosterol, stigmasterol, lupeol, campesterol, and squalene. Seeds of Parkia speciosa are used traditionally to treat diabetes, high blood pressure, and kidney complications. Per $100 \mathrm{~g}$ of fresh seeds, contains $6.0 \mathrm{~g}$ protein, $1.6 \mathrm{~g}$ fat, $13.2 \mathrm{~g}$ carbohydrate, $1.7 \mathrm{~g}$ crude fiber, and $91.0 \mathrm{kcal}$ energy. A same amount of seeds contains $108.0 \mathrm{mg}$ calcium, $2.2 \mathrm{mg}$ iron, $115.0 \mathrm{mg}$ phosphorus, $341.0 \mathrm{mg}$ potassium, $29.0 \mathrm{mg}$ magnesium, $19.3 \mathrm{mg}$ vitamin c, $4.15 \mathrm{mg}$ a-Tocopherol, and $0.28 \mathrm{mg}$ thiamin. Parkia speciosa gives anti-oxidant, hypoglycemic, anti-tumor, and anti-mutagenicity, anti-microbial activities $^{42}$. 

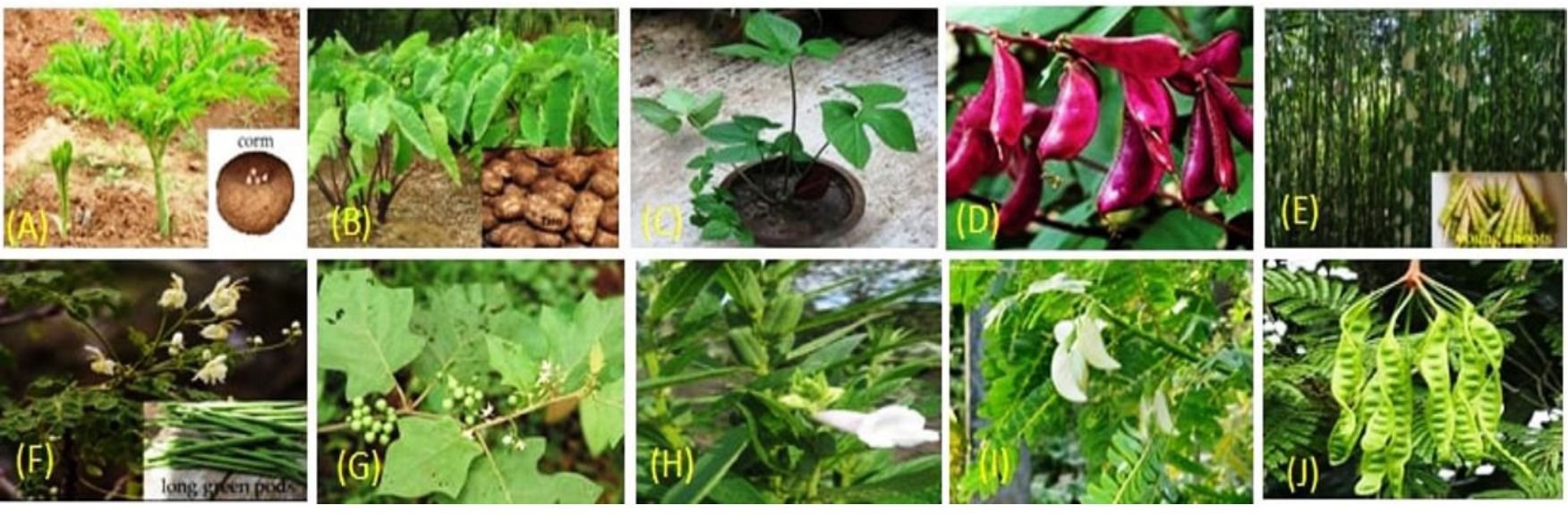

Figure 1. (A) Amorphophallus paeoniifolius, (B) Colocasia esculenta, (C) Typhonium trilobatu, (D) Lablab purpureus, (E) Melocanna baccifera, (F) Moringa oleifera, (G) Solanum torvum, (H) Sesamum indicum, (I) Sesbenia grandiflora, (J) Parkia speciosa.

\section{Fruit Group's Plants}

\subsection{Banana (Musa paradisiaca)}

Musa paradisiaca (Banana) (Figure 2A) is one of the wellknown herbaceous flowering plants. Banana is one of the majors and economically important fruit crop in India. The entire lower parts of Himalaya are rich in banana plantation because of the suitable range of temperature (15-350C), humidity (75-85\%), and loamy soil type. The primary harvesting season of banana is from September to April. Fruit, stem, and flower are edible parts of banana. The taxonomical classification of Musa paradisiacal is described in Table $11^{43}$.

Table 11. Taxonomical classification of Musaparadisiaca

\begin{tabular}{|c|c|}
\hline Kingdom & Plantae \\
\hline Phylum & Tracheophyta \\
\hline Class & Liliopsida \\
\hline Order & Zingiberales \\
\hline Family & Musaceae \\
\hline Genus & Musa \\
\hline Species & M. paradisiacal \\
\hline
\end{tabular}

Banana fruits, stem, and flowers contain alkaloids, phenols, flavonoids (quercetin), tannins, glycosides (a phenylpropanoid glycoside analogs), saponins, and volatile oils, respectively ${ }^{44,45}$. Flowers are used in dysentery, diabetes, and menorrhagia. Stems juice is used for treating diarrhea, dysentery, cholera, otalgia, and hemoptysis. Fruit (unripe) is used for diarrhea, dysentery, intestinal lesions in ulcerative colitis, diabetes, in sprue, uremia, nephritis, gout, hypertension, and cardiac diseases ${ }^{45}$. Nutritional values per $100 \mathrm{~g}$ of flowers consist of $1.6 \mathrm{~g}$ protein, $0.6 \mathrm{~g}$ fat, $9.9 \mathrm{~g}$ carbohydrate, $5.7 \mathrm{~g}$ crude fiber, $51 \mathrm{Kcal}$ energy, $553.3 \mathrm{mg}$ potassium, $73.3 \mathrm{mg}$ phosphorus, $56 \mathrm{mg}$ calcium, $56.4 \mathrm{mg}$ iron, and $1.07 \mathrm{mg}$ of Vit. E. Nutritional values per $100 \mathrm{~g}$ of raw stem consist of 1 $\mathrm{g}$ protein, $0 \mathrm{~g}$ fat, $2 \mathrm{~g}$ carbohydrate, $2 \mathrm{~g}$ crude fiber, $13 \mathrm{Kcal}$ energy, $137 \mathrm{mg}$ phosphorus, $1335 \mathrm{mg}$ calcium, and 3.31 $\mathrm{mg}$ iron. Dietary contents per $100 \mathrm{~g}$ of ripe fruit consist of $1.09 \mathrm{~g}$ protein, $0.33 \mathrm{~g}$ fat, $2.842 \mathrm{~g}$ carbohydrate, $260 \mathrm{~g}$ crude fiber, $89 \mathrm{Kcal}$ energy, $358 \mathrm{mg}$ potassium, $22 \mathrm{mg}$ phosphorus, $5 \mathrm{mg}$ calcium, and $0.26 \mathrm{mg}$ iron, $64 \mathrm{mg}$ Vit. A, $9.7 \mathrm{mg}$ Vit. C and $0.10 \mathrm{mg}$ Vit. $\mathrm{E}^{46-48}$. Banana is a low cost, highly economical fruit in India. Biological activities of edible parts of banana are minimizing diabetes and anemia, boost lactation, decrease free radical activity, curing menses complications, and reduce anxiety ${ }^{45}$.

\subsection{Pineapple (Ananas comosus)}

Ananas comosus (Figure 2B) is the accepted name for the commonly known pineapple fruit. It is an herbaceous perennial plant. The adult plant will grow $1 \mathrm{~m}-1.5 \mathrm{~m}$ tall and inscribed in the general shape of a spinning top. This plant mostly grows in tropical forests, and the primary fruiting season is from April to May. In northeast India, pineapple is favorite for the fruit lovers in its fresh as well as processed forms like jam, jelly, and squashes. The taxonomical classification of Ananas comosus is described in Table $12^{49}$. 
Table 12. Taxonomical classification of Ananas comosus

\begin{tabular}{|c|c|}
\hline Kingdom & Plantae \\
\hline Phylum & Tracheophyta \\
\hline Class & Lilopsida \\
\hline Order & Bromeliales \\
\hline Family & Bromeliaceae \\
\hline Genus & Ananas \\
\hline Species & A. comosus \\
\hline
\end{tabular}

Phytochemical analysis for pineapple fruit juice shows the existence of phenols, flavonoids, steroids, tannins, saponins, alkaloids, and volatile and non-volatile compounds ${ }^{50}$. The valuable phenols were gallic acid, catechin, epicatechin, ferulic acid, caffeic acid, sinapic acid, ellagic acid, and vanillin ${ }^{51}$. Identified major flavonoid and isoflavone compounds of pineapple fruit were rutin, isoquercetin, and genistin ${ }^{52}$. Identified primary non-volatile organic acids were malic acid, quinic acid, and citric acid. Major volatile compounds were methyl-3-(methylthio) propionate, ethyl-3-(methylthio) propionate, 3-hydroxy-2-butanone, furaneol, ethyl-2methyl butanoate, hexanoic acid, nonanoic acid, decanoic acid, $\beta$-guaiene ${ }^{53}$. Khamptis tribe of Arunachal Pradesh, India, used burnt fruit for the treatment of urinary tract ailments (Khongsai et al. 2011). Bamileke, communities in the Douala region of Cameroon, used Ananas comosus fruit to relieve yellow fever, obesity, prevention against cancer, Vit. C maintenance and leaves were used to relieve cough and jaundice ${ }^{54}$.Fresh juices of pineapple are rich sources of minerals, vitamins, and energy. Nutritional values per $100 \mathrm{~g}$ of fruit juice consist $0.54 \mathrm{~g}$ protein, 0.12 $\mathrm{g}$ fat, $13.52 \mathrm{~g}$ carbohydrate, $1.40 \mathrm{~g}$ crude fiber, $50 \mathrm{Kcal}$ energy, $109 \mathrm{mg}$ potassium, $1 \mathrm{mg}$ sodium, $0.110 \mathrm{mg}$ copper, $13 \mathrm{mg}$ calcium, and $0.29 \mathrm{mg}$ iron, $0.500 \mathrm{mg}$ niacin, 0.079 $\mathrm{mg}$ thiamine, $58 \mathrm{IU}$ Vit. A and $47.8 \mathrm{mg}$ Vit. $\mathrm{E}^{55}$. Biological activities of pineapple fruit extracts possess anti-bacterial, anti-viral, anti-fungal, anti-parasitic, anti-inflammatory, anti-oxidant, anti-rheumatic, and anti-diarrheal ${ }^{56}$.

\subsection{Jackfruit (Artocarpus heterophyllus)}

Jackfruit or Artocarpus heterophyllus (Figure 2C) is a tropical evergreen perennial plant of height up to 20 m. Fruits bear from June to August. Fruit and seed are the main edible parts of jackfruit. The Taxonomical classification of Artocarpus heterophyllus is represented in Table $13^{57}$.
Table 13. Taxonomical classification of Artocarpus heterophyllus

\begin{tabular}{|c|c|}
\hline Kingdom & Plantae \\
\hline Phylum & Tracheophyta \\
\hline Class & Magnoliopsida \\
\hline Order & Urticales \\
\hline Family & Moraceae \\
\hline Genus & Artocarpus \\
\hline Species & A. heterophyllus \\
\hline
\end{tabular}

Artocarpus heterophyllus contains morin, dihydromorin, cynomacurin, artocarpin, isoartocarpin, cyloartocarpin, artocarpesin, oxydihydroartocarpesin, artocarpetin A, artocarpetin B, norartocarpetin, cycloartinol and artocarpanone. The plant also comprises fatty acids, ellagic acid, and some essential amino acids like arginine, cystine, histidine, leucine, lysine, methionine, threonine, tryptophan, etc. heteroflavanones A and B were isolated from the root bark. The fresh fruits are worthwhile in astringent and carminative. The mature fruits are syrupy, cooling, purgative, aphrodisiac, and available as a brain tonic. The seeds are diuretic and obstipation. The wood is nervine, anti-diabetic, tranquilizing, and is helpful in seizures $^{57}$. Nutritional values per $100 \mathrm{~g}$ of jackfruit juice consist of $1.72 \mathrm{~g}$ protein, $0.64 \mathrm{~g}$ fat, $23.5 \mathrm{~g}$ carbohydrate, $1.5 \mathrm{~g}$ crude fiber, $95 \mathrm{Kcal}$ energy, $303 \mathrm{mg}$ potassium, 3 $\mathrm{mg}$ sodium, $34 \mathrm{mg}$ calcium, and $0.60 \mathrm{mg}$ iron, $0.920 \mathrm{mg}$ niacin, $110 \mathrm{IU}$ Vit. A, $13.7 \mathrm{mg}$ Vit.C and $0.34 \mathrm{mg}$ it. E. Nutritional values per $100 \mathrm{~g}$ of jackfruit seeds consist of $7 \mathrm{~g}$ protein, $1 \mathrm{~g}$ fat, $38 \mathrm{~g}$ carbohydrate, $1.5 \mathrm{~g}$ crude fiber, $184 \mathrm{Kcal}$ energy, $1.30 \mathrm{mg}$ potassium, $30 \mathrm{mg}$ sodium, 0.02 $\mathrm{mg}$ calcium, and $1.5 \mathrm{mg}$ iron, $10 \mathrm{IU}$ Vit. A and $11 \mathrm{mg}$ Vit. $\mathrm{C}^{58,59}$. The principle biological properties of jackfruit are anti-ulcer and cardiovascular, improving digestion, anti-oxidant, skin diseases, anti-cancer, and anti-aging activities. A jackfruit seeds starch is used to reduce stomach sickness. Roasted seeds possess aphrodisiac properties $^{60}$.

\subsection{Gaub Tree (Diospiros malabarica)}

Diospyros malabarica (Figure 2D) is a perennial, blossoming bush that is inherent in the Indian subcontinent. It is slow developing, well-branched, and has an extended crown and a long, cylindrical trunk that raises about $70 \mathrm{~cm}$ in diameter. It extends a height of about $37 \mathrm{~m}$. The leaves are sparkly olive, and the flowers are white or green. This plant is grown in the lowland rainforests zone of lower Himalayan reason. A flowering 
season is from January to February. Ripe fruits are the edible part of this plant. The taxonomical classification of Diospiros malabarica is represented in Table $14^{61}$.

Table 14. Taxonomical classification of Diospiros malabarica

\begin{tabular}{|c|c|}
\hline Kingdom & Plantae \\
\hline Phylum & Tracheophyta \\
\hline Class & Magnoliopsida \\
\hline Order & Ericales \\
\hline Family & Ebenaceae \\
\hline Genus & Diospyros \\
\hline Species & D. malabarica \\
\hline
\end{tabular}

Leaves contain $\beta$-sitosterol, betulin, oleanolic acid and myricyl alcohol. Fruits contain new lupine-type triterpenes- peregrinol and bark consist of saponin, betulinic acid. Traditionally the fruits are used as bitter, acrid, cooling, digestive, carminative ${ }^{62}$. Per $100 \mathrm{~g}$ of eatable part of fruits contains $1.36 \mathrm{~g}$ protein, $0.17 \mathrm{~g}$ fat, $20.34 \mathrm{~g}$ carbohydrate, $1.59 \mathrm{~g}$ crude fiber, and $88.36 \mathrm{kcal}$ energy. Per $100 \mathrm{~g}$ of fruits contains $0.07 \mathrm{mg}$ copper, 0.46 $\mathrm{mg}$ manganese, and $0.08 \mathrm{mg} \mathrm{zinc}{ }^{63}$. The fruits showed anthelmintic activity in a dose-dependent manner, antibacterial activity, anti-fungal activity, hepatoprotective activity, and anti-oxidant activity ${ }^{62}$.

\subsection{Custard Apple (Annona reticulate)}

Annona reticulata (Figure $2 \mathrm{E}$ ) is a small deciduous or semi-evergreen tree. It has well known for its fruit, called custard apple. The plant needs a tropical climate for proper growth, but it can survive in subtropical conditions-this plant mostly located in northeast India, such as Tripura, Assam, and Manipur. The taxonomical classification of Annona reticulata is represented in Table $15^{64}$.

Table 15. Taxonomical classification of Annona reticulata

\begin{tabular}{|c|c|}
\hline Kingdom & Plantae \\
\hline Phylum & Tracheophyta \\
\hline Class & Magnoliosida \\
\hline Order & Magnoliales \\
\hline Family & Annonaceae \\
\hline Genus & Annona \\
\hline Species & A. reticulate \\
\hline
\end{tabular}

Ethyl acetate extract of seeds of Annona reticulata consists of cis-/trans-isomurisolenin, annoreticuin, annoreticuin-9-one, cis-/trans-bullatacinone, bullatacin, cis-trans-murisolinone, and squamocin. Annonaretin A, a new triterpenoid, was chemically investigated from the leaves (Chavan et al. 2014). Raw fruit peel extracts contain alkaloids, cholesterol, coumarins, flavonoids, phenols, and saponins. Traditionally the unripe fruit is used for dysentery and diarrhea. Leaves are used to prepare tea for relieving colic. A decoction of the leaves is used mostly in reducing malaria and syphilis. The roots used to reduce epilepsy ${ }^{64}$. Per $100 \mathrm{~g}$ of eatable part of fruits contains 1.98 g protein, $0.10 \mathrm{~g}$ fat, $27.49 \mathrm{~g}$ carbohydrate, $1.59 \mathrm{~g}$ crude fiber, and $118.84 \mathrm{kcal}$ energy. Per $100 \mathrm{~g}$ of fruits contains $0.15 \mathrm{mg}$ copper, $0.02 \mathrm{mg}$ iron, $0.01 \mathrm{mg}$ manganese, and $0.21 \mathrm{mg}$ zinc. The fruits also contained a good amount of vitamin C (37.40 mg/100 g $)^{63}$. Custard apple seed extract is potent for the remedy of the liver, prostate, pancreatic, cervical cancers, and leukemia. Fruit pulp possesses anti-oxidant activity, anti-diabetic, and anti-cancer properties $^{65}$.

\subsection{Sugar Apple (Annona squamosa)}

Annona squamosa (Figure $2 \mathrm{~F}$ ) is a pint-sized, semievergreen tree that is 3-7 $\mathrm{m}$ tall and widely unfold crown or unevenly distribute branches. Leaves are single, 6-17 x 3-6 cm, lanceolate or oblong-lanceolate. Flowers are greenish-yellow, fragrant, on slender hairy stalks. The accumulated fruit is formed together by various pistils of a flower, which are lightly joined together. The taxonomical classification of Annona squamosa is described in Table $16^{66}$.

Table 16. Taxonomical classification of Annona squamosa

\begin{tabular}{|c|c|}
\hline Kingdom & Plantae \\
\hline Phylum & Tracheophyta \\
\hline Class & Magnoliosida \\
\hline Order & Magnoliales \\
\hline Family & Annonaceae \\
\hline Genus & Annona \\
\hline Species & A. squamosa \\
\hline
\end{tabular}

The fruit pulp of Annona squamosa contains alkaloids, tannins, flavonoids, saponins, terpenoids, glycosides, and steroids. The fruit also contains Annonaceous acetogenins, cyclopeptides ${ }^{67}$. Traditionally the leaf, bark, and unripe fruit were used for diarrhea and dysentery ${ }^{68}$. 
Per $100 \mathrm{~g}$ of eatable part of fruits contains $5.44 \mathrm{~g}$ protein, $0.067 \mathrm{~g}$ fat, $20.41 \mathrm{~g}$ carbohydrate, $2.78 \mathrm{~g}$ crude fiber, and $92.90 \mathrm{kcal}$ energy. Per $100 \mathrm{~g}$ of fruits pulp contains 602.5 mg calcium, $9.500 \mathrm{mg}$ copper, $48.08 \mathrm{mg}$ iron, $5.569 \mathrm{mg}$ manganese, and $28.68 \mathrm{mg}$ zinc, $52.5 \mathrm{mg}$ magnesium, 80.0 $\mathrm{mg}$ phosphorus, $618 \mathrm{mg}$ potassium, $22.5 \mathrm{mg}$ sodium. The fruits were also content a good amount of vitamin C $(90.7$ $\mathrm{mg} / 100 \mathrm{~g})$ and vitamin A (150 IU/100 g) ${ }^{69,70}$. Annona squamosa possesses anti-diabetic and hypolipidemic, anti-oxidant, anti-inflammatory, analgesic, antihypertensive, hepatoprotective, anti-parasitic, antimalarial, insecticidal, and anti-microbial activities ${ }^{68}$.

\subsection{Indian Jujube (Ziziphus jujuba)}

It is a tiny deciduous tree or shrub of 5-12 meters (16-39 $\mathrm{ft})$ height, generally with much thorny brushwood. The leaves are glossy-green, ovate-acute, 2-7 centimeters. February to March is the flowering reason of Ziziphus jujuba (Figure 2G). The fruits were mature between 2 and 3 months after flowering. The taxonomical classification of Ziziphus jujuba is described in Table $17^{71}$.

Table 17. Taxonomical classification of Ziziphus jujuba

\begin{tabular}{|c|c|}
\hline Kingdom & Plantae \\
\hline Phylum & Tracheophyta \\
\hline Class & Magnoliopsida \\
\hline Order & Rosales \\
\hline Family & Rhamnaceae \\
\hline Genus & Ziziphus \\
\hline Species & Z.jujaba \\
\hline
\end{tabular}

Fruit of Z. jujuba contains phenolic acids, flavonoids, anthocyanins, and proanthocyanidin. Identified phenolic acids were p-coumaric acid, cinnamic acid, caffeic acid, chlorogenic acid, ferulic acid, gallic acid, and vanillic acid. Determined flavonoids were quercetin, rutin, quercetin-3-galactoside, quercetin-3rutinoside, kaempferol-glucosyl-rhamnoside, quercetin3-robinobioside, epicatechin, catechin, and procyanidin $\mathrm{B}^{72}$. Fruits are used traditionally as cooling, digestible, tonic, aphrodisiac, and laxative and remove biliousness, burning sensations, thirst, and vomiting. The leaves are antipyretic and reduce obesity. The folk practitioners avail the fresh leaves with cumin to cure the urinary disorder. The bark of the tree is used for the remedy of dysentery and diarrhea. New roots are used to treat throat hoarseness $^{73}$. Per $100 \mathrm{~g}$ of fresh fruits, contain $1.20 \mathrm{~g}$ protein, $0.20 \mathrm{~g}$ lipid, $20.23 \mathrm{~g}$ carbohydrate, $1.7 \mathrm{~g}$ crude fiber, and $79 \mathrm{kcal}$ energy. A similar amount of fruits contains $21 \mathrm{mg}$ calcium, $0.48 \mathrm{mg}$ iron, $23 \mathrm{mg}$ phosphorus, $250 \mathrm{mg}$ potassium, $3 \mathrm{mg}$ sodium, $10 \mathrm{mg}$ magnesium, 69.0 $\mathrm{mg}$ vitamin $\mathrm{C}$, and $40 \mathrm{IU}$ vitamin A. Ziziphus jujuba possesses anti-cancer, anti-inflammatory, anti-obesity, immunostimulating, anti-oxidant, and hepatoprotective properties $^{72}$.

\subsection{Pummelo (Citrus maxima)}

Citrus maxima (Figure 2H) is a tree of 5-15 $\mathrm{m}$ height, with a somewhat crooked trunk $10-30 \mathrm{~cm}$ thick, low branches, asymmetrical, and extending. Leaves are compound, appearing dull, having one leaflet. Flowers are fragrant, borne singly, and fruit ranges tightly curved to oblate or pear-form. Early April is the flowering season of this plant. The taxonomical classification of Citrus maxima is described in Table $18^{74}$.

Table 18. Taxonomical classification of Citrus maxima

\begin{tabular}{|c|c|}
\hline Kingdom & Plantae \\
\hline Phylum & Tracheophyta \\
\hline Class & Magnoliopsida \\
\hline Order & Sapindales \\
\hline Family & Rutaceae \\
\hline Genus & Citrus \\
\hline Species & C. maxima \\
\hline
\end{tabular}

Citrus maxima contain alkaloids, phenols, flavonoids, monoterpenes, and sesquiterpenes. 5-hydroxyacronycine, acriginine $\mathrm{A}$, atalafoline, baiyumine $\mathrm{A}$ and $\mathrm{B}$, buntanine, buntanmine, grandisine I and II, pumiline, honyumine, natsucrin, prenylcitpressine, citropone A \& B, and glycocitrine I identified alkaloids were existing in the roots and the bark of the plant. Acacetin, rutin, tangeretin, cosmosiin, diosmetin, diosmin, eriocitrin, hespeidin, and naringin were identified flavonoids. Identified steroids: were $\beta$-Sitosterol, campesterol, daucosterol, stigmasterol. Leaves are used for the treatment of epilepsy, chorea, and convulsive cough and given for hemorrhage disease. Flowers are used for the treatment of tranquilizer in nervous affection, and fruits are used to treat leprosy, hiccough, mental aberration, and cardiotonic $^{74}$. Per $100 \mathrm{~g}$ of fresh fruits, contain $0.76 \mathrm{~g}$ protein, $0.04 \mathrm{~g}$ fat, $9.62 \mathrm{~g}$ carbohydrate, $1 \mathrm{~g}$ crude fiber, and $38 \mathrm{kcal}$ energy. A 
similar amount of fruits contains $0.11 \mathrm{mg}$ iron, $17 \mathrm{mg}$ phosphorus, $216 \mathrm{mg}$ potassium, $1 \mathrm{mg}$ sodium, $10 \mathrm{mg}$ magnesium, $61 \mathrm{mg}$ vitamin C, $0.034 \mathrm{mg}$ thiamine, 0.027 $\mathrm{mg}$ riboflavin, and $0.22 \mathrm{mg}$ niacin $^{75}$. Citrus maxima give anti-oxidant, anti-inflammatory, anti-diabetic, anti-tumor, hepatoprotective, anti-bacterial, and CNS stimulant activities $^{74}$.

\section{Results from Literature Survey}

\subsection{Plants of Vegetable Group}

The literature survey observed that ten vegetable plants have medicinal values and nutritional importance (Table 19). These ten vegetable plants have contained alkaloids, phenols, flavonoids, tannins, terpenoids, glycosides, etc.
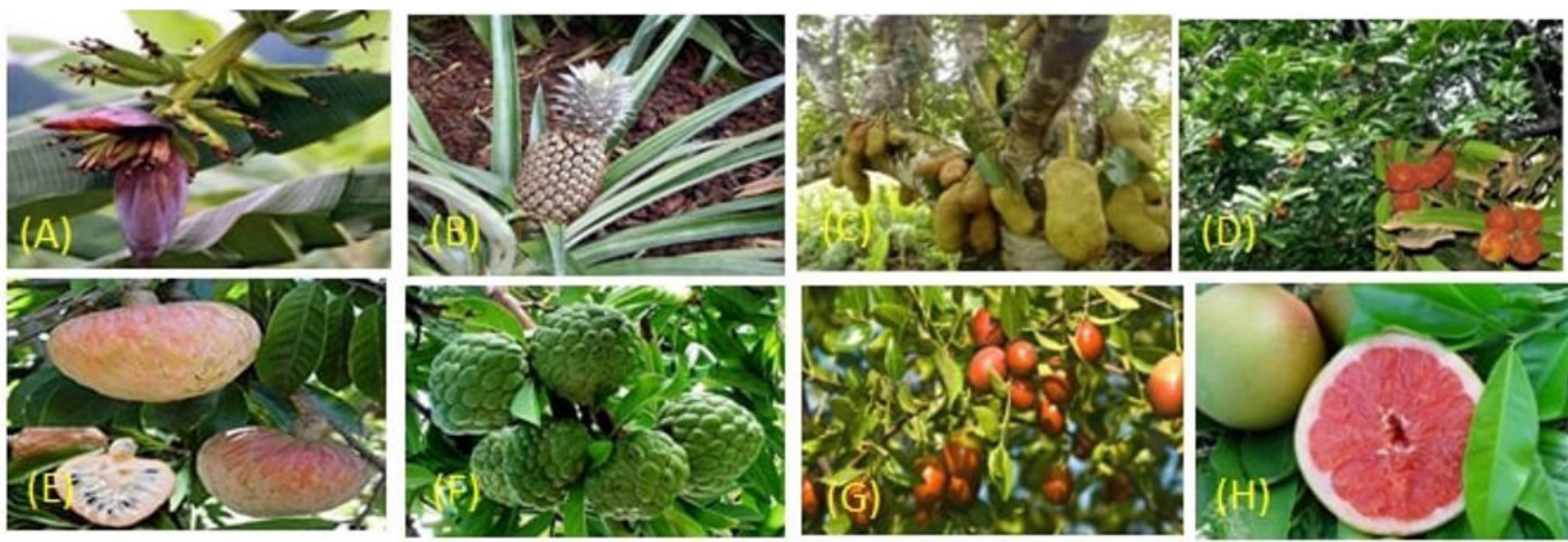

Figure 2. (A) Musa paradisiac,(B) Ananas comosus, (C) Artocarpus heterophyllus, (D) Diospiros malabarica, (E) Annona reticulate, (F) Annona squamosal, (G) Ziziphus jujube, (H) Citrus maxima.

Table 19. Summary of vegetable group plants

\begin{tabular}{|c|c|c|c|c|}
\hline $\begin{array}{l}\text { Botanical name and } \\
\text { family }\end{array}$ & $\begin{array}{l}\text { Edible } \\
\text { parts }\end{array}$ & $\begin{array}{c}\text { Energy content } \\
\text { per } 100 \mathrm{~g}\end{array}$ & Biological activities & Citations \\
\hline $\begin{array}{l}\text { Amorphophallus } \\
\text { paeoniifolius } \\
\text { (Araceae) }\end{array}$ & Corm & $359.08 \mathrm{Kcal}$ & $\begin{array}{l}\text { Anti-inflammatory, CNS depressant, anti-microbial, } \\
\text { anthelmintic, hepatoprotective, anti-oxidant, }\end{array}$ & {$[8,9]$} \\
\hline \multirow{2}{*}{$\begin{array}{l}\text { Colocasia esculenta } \\
\text { (Araceae) }\end{array}$} & Corm & $85 \mathrm{Kcal}$ & \multirow{2}{*}{ Anti-microbial, anti-oxidant, and anti-diabetic activities } & \multirow{2}{*}[10-18]{} \\
\hline & Leaf & $69 \mathrm{Kcal}$ & & \\
\hline $\begin{array}{l}\text { Typhonium trilobatum } \\
\text { (Araceae) }\end{array}$ & Leaf & $28.94 \mathrm{Kcal}$ & $\begin{array}{l}\text { Anti-inflammatory, analgesic, wound healing, anti- } \\
\text { bacterial, anti-fungal, anti-diarrheal, and anti-diarrheal. }\end{array}$ & {$[1,19,20]$} \\
\hline $\begin{array}{l}\text { Lablab purpureus } \\
\quad \text { (Fabaceae) }\end{array}$ & Seed & $344 \mathrm{Kcal}$ & $\begin{array}{l}\text { Anti-inflammatory, anti-oxidant, anti-bacterial and } \\
\text { cytotoxicity activities }\end{array}$ & {$[21-24]$} \\
\hline $\begin{array}{l}\text { Melocanna baccifera } \\
\text { (Poaceae) }\end{array}$ & Shoot & $204.93 \mathrm{kcal}$ & Anti-oxidant activity & {$[25,28]$} \\
\hline \multirow{3}{*}{$\begin{array}{l}\text { Moringa oleifera } \\
\text { (Moringaceae) }\end{array}$} & Leaf & $92 \mathrm{Kcal}$ & \multirow{3}{*}{$\begin{array}{l}\text { Hypolipidemic, anti-peroxidative, cardioprotective, } \\
\text { anti-oxidant, anti-inflammatory, anti-nociceptive, anti- } \\
\text { microbial, hepatoprotective, anti-hyperglycemic and } \\
\text { anti-atherosclerotic activities }\end{array}$} & \multirow{3}{*}{ [29-31] } \\
\hline & Flower & $17.95 \mathrm{Kcal}$ & & \\
\hline & Green pod & $26 \mathrm{Kcal}$ & & \\
\hline $\begin{array}{l}\text { Solanum torvum } \\
\text { (Solanaceae) }\end{array}$ & Fruit & $39.96 \mathrm{Kcal}$ & $\begin{array}{l}\text { Anti-oxidant, anti-fungal, anti-bacterial, anti-ulcer, anti- } \\
\text { hypertensive and metabolic correction }\end{array}$ & [32-33] \\
\hline $\begin{array}{l}\text { Sesamum indicum } \\
\text { (Padaliaceae) }\end{array}$ & Seed & $573 \mathrm{Kcal}$ & $\begin{array}{c}\text { Regulates cholesterol, neurological role, and blood } \\
\text { pressure }\end{array}$ & [34-36] \\
\hline
\end{tabular}




\begin{tabular}{|c|c|c|c|c|}
\hline \multirow{2}{*}{$\begin{array}{l}\text { Sesbania grandiflora } \\
\text { (Fabaceae) }\end{array}$} & Leaf & $93 \mathrm{kcal}$ & \multirow{2}{*}{$\begin{array}{l}\text { Anti-microbial activity, decreased serum cholesterol } \\
\text { levels, wound healing activity, and anti-ulcer activity }\end{array}$} & \multirow{2}{*}{ [37-41] } \\
\hline & Flower & $27 \mathrm{kcal}$ & & \\
\hline $\begin{array}{l}\text { Parkia speciosa } \\
\text { (Fabaceae) }\end{array}$ & Seed & $91.0 \mathrm{kcal}$ & $\begin{array}{l}\text { Anti-oxidant, hypoglycemic, anti-tumor, and anti- } \\
\text { mutagenicity, anti-microbial activities }\end{array}$ & [42] \\
\hline
\end{tabular}

\subsection{Plants of Fruit Group}

The literature survey observed that eight fruit plants have medicinal values and nutritional importance (Table 20). These eight fruit plants have also contained bioactive compounds. The important bioactive compounds are alkaloids, phenols, flavonoids, tannins, terpenoids, glycosides, etc.

Table 20. Summary of fruit group plants

\begin{tabular}{|c|c|c|c|c|}
\hline $\begin{array}{l}\text { Botanical name and } \\
\text { family }\end{array}$ & $\begin{array}{l}\text { Edible } \\
\text { parts }\end{array}$ & $\begin{array}{l}\text { Energy content } \\
\text { per } 100 \mathrm{~g}\end{array}$ & Biological activities & Citations \\
\hline \multirow{3}{*}{$\begin{array}{l}\text { Musa paradisiaca } \\
\text { (Musaceae) }\end{array}$} & Flower & $51 \mathrm{Kcal}$ & \multirow{3}{*}{ Anti-diabetic, anti-oxidant, anti-hypertension activities } & \multirow{3}{*}[43-48]{} \\
\hline & Stem & $13 \mathrm{Kcal}$ & & \\
\hline & Fruit & $89 \mathrm{Kcal}$ & & \\
\hline $\begin{array}{l}\text { Ananas comosus } \\
\text { (Bromeliaceae) }\end{array}$ & Fruit & $50 \mathrm{Kcal}$ & $\begin{array}{l}\text { Anti-bacterial, anti-viral, antifungal, antiparasitic, anti- } \\
\text { inflammatory, anti-oxidant, anti-rheumatic, and anti- } \\
\text { diarrheal }\end{array}$ & [49-56] \\
\hline $\begin{array}{l}\text { Artocarpus } \\
\text { heterophyllus } \\
\text { (Moraceae) }\end{array}$ & Fruit & $95 \mathrm{Kcal}$ & $\begin{array}{c}\text { Anti-ulcer and cardiovascular, improving digestion, anti- } \\
\text { oxidant, skin diseases }\end{array}$ & {$[57-60]$} \\
\hline $\begin{array}{l}\text { Diospiros malabarica } \\
\text { (Ebenaceae) }\end{array}$ & Fruit & $88.36 \mathrm{kcal}$ & $\begin{array}{l}\text { Anti-bacterial, anti-fungal, hepatoprotective, and anti- } \\
\text { oxidant activities }\end{array}$ & {$[61-63]$} \\
\hline $\begin{array}{l}\text { Annona reticulate } \\
\text { (Annonaceae) }\end{array}$ & Fruit & $118.84 \mathrm{kcal}$ & $\begin{array}{l}\text { Anti-oxidant activity, anti-diabetic, and anti-cancer } \\
\text { properties }\end{array}$ & {$[64,65]$} \\
\hline $\begin{array}{c}\text { Annona squamosa } \\
\text { (Annonaceae) }\end{array}$ & Fruit & $92.90 \mathrm{kcal}$ & $\begin{array}{l}\text { Anti-diabetic and hypolipidemic, anti-oxidant, anti- } \\
\text { inflammatory, analgesic, anti-hypertensive activities }\end{array}$ & {$[66-70]$} \\
\hline Ziziphusjujuba & Fruit & 79 kcal & $\begin{array}{l}\text { Anti-cancer, anti-inflammatory, anti-obesity, } \\
\text { immunostimulating, anti-oxidant, and hepatoprotective } \\
\text { properties }\end{array}$ & {$[71-73]$} \\
\hline $\begin{array}{l}\text { Citrus maxima } \\
\text { (Rutaceae) }\end{array}$ & Fruit & $38 \mathrm{kcal}$ & $\begin{array}{c}\text { Anti-oxidant, anti-inflammatory, anti-diabetic, anti- } \\
\text { tumor, hepatoprotective, anti-bacterial, and CNS } \\
\text { stimulant activities }\end{array}$ & {$[74,75]$} \\
\hline
\end{tabular}

\section{Discussion}

Edible medicinal plants are food-based plants those fulfill the dietary supplement and minimize chronic diseases ${ }^{76}$. The acute toxicity studies observed that edible medicinal plant parts do not shown any toxic effects at a maximum doses ${ }^{77-79}$. Phytochemicals are biologically active, naturally occurring secondary plant metabolites. The traditional medicinal knowledge and biological activity of the plant species depended on the presence of different phytochemicals ${ }^{80,81}$. The literature revealed that eighteen edible medicinal plants have contained common phytochemicals like alkaloids, phenolic, flavonoids, terpenoids, tannin, glycosides and gave various traditional medicinal values and biological activities represented in the Tables 19 and 20. Nutritional assessment refers to the contents of micronutrients and macronutrients of the food samples and the impact on the body. Most of the Indian peoples have suffering malnutrition (especially scurvy, rickets, beriberi, etc.) for deficiency of nutrients ${ }^{82}$. If Indian peoples take periodically various seasonal vegetables and food in their 
diet, then it can be easily minimizing the malnutrition deficiencies ${ }^{83}$. Energy content on food is a vital property. The energy level (Table $19 \& 20$ ) depends on the total amount of carbohydrate, protein, and fat present in the food samples ${ }^{84}$. Traditional medicinal knowledge of plant species is essential for herbal drug development. It is a way to save the cultural therapeutic wisdom from the different ethnic communities of India ${ }^{85}$. In this review it was noticed that all the edible plant parts have traditional values.

\section{Conclusion}

In this review, we have focused on eighteen edible plants in Tripura, India for their nutraceutical values. Consumable parts of selected plants showed the right amount of proximate composition, minerals, and vitamins. These edible plant parts also diminish the possible causes like high blood pressure, diabetes, cardiovascular diseases, and may help to prevent cancer. This review helps natural product researchers to find out the new floras of Tripura with their biological and nutritional importance.

\section{Conflict of Interest}

The authors declare no conflict of interest.

\section{Acknowledgement}

The authors are grateful for the e-resources provided by Tripura University (A Central University), Suryamaninagar, Tripura, India-799022.

\section{Funding Sources}

Indian Council of Medical Research (ICMR) (No. 3/1/2/125/2019-(Nut) and All India Council for Technical Education (AICTE) (No. 8-114/RIFD/RPSNER/Policy-1/2018-19) providing financial support.

\section{References}

1. Manna K, Debnath B, Das M, Marwein SA. Comprehensive review on pharmacognostical investigation and pharmacology of Typhonium trilobatum. Nat Prod J. 2016; 6:172-8. https://doi.org /10.2174/2210315506666160810145157

2. Prakash D, Gupta C, Sharma G. Importance of phytochemicals in nutraceuticals. J Chin Med Res. 2012; 1:70-8.
3. Shikov AN, Tsitsilin AN, Pozharitskaya ON, Makarov VG, Heinrich M. Traditional and current food use of wild plants listed in the Russian Pharmacopoeia. Front Pharmacol. 2017; 8:841. https://doi.org/10.3389/ fphar.2017.00841

4. Aberoumand A. Protein, fat, calories, minerals, phytic acid and phenolic in some plant foods based diet. J Food Processing Techno. 2011; 2:1-4. https:// doi.org/10.4172/2157-7110.1000114

5. Mehra A, Bajpai O, Joshi H. Diversity, utilization and sacred values of ethno-medicinal plants of Kumaun Himalaya. Trop. Plant Res. 2014; 1:80-6.

6. Joshi R, Satyal P, Setzer W. Himalayan aromatic medicinal plants: A review of their ethnopharmacology, volatile phytochemistry, and biological activities. Medicines. 2016; 3:6. https://doi. org/10.3390/medicines3010006

7. Deb DB. The flora of Tripura State. New Delhi: Today and Tomorrow's Printers and Publishers.1981-1983; $1(2)$.

8. Dey YN, Ota S, Srikanth N, Jamal M, WanjariM. A phytopharmacological review on an important medicinal plant- Amorphophallus paeoniifolius. Ayu. 2012; 33:27-32. https://doi.org/10.4103/09748520.100303

9. Srivastava S, Verma D, Srivastava A, Tiwari SS, Dixit B, Singh RS, Rawat AK. Phytochemical and nutritional evaluation of Amorphophallus campanulatus (Roxb.) Blume Corm J Nutr Food Sci. 2014; 4:1-6. https:// doi.org/10.4172/2155-9600.1000274

10. Prajapati R, Kalariya M, Umbarkar R, Parmar S, Sheth N. Colocasia esculenta: A potent indigenous plant. Int. J. Nutr. Pharmacol. Neurol. Dis. 2011; 1:90-96. https://doi.org/10.4103/2231-0738.84188

11. Nakade D, Mahesh S, Kiran N, Vinayak S. Phytochemical screening and antibacterial activity of western region wild leaf of Colocasia esculenta. IntResJBiolSci. 2013; 2:18-21.

12. Alcantara MA, Hurtada WA, Dizon EI. The nutritional value and phytochemical components of taro [Colocasia esculenta (L.) Schott] powder and its selected processed foods. Food SciNutr. 2013. https:// doi.org/10.4172/2155-9600.1000207

13. Ogukwe CE, Amaechi PC, Enenebeaku CK. Studies on the flowers and stems of two cocoyam varieties: Xanthosoma sagittifolium and Colocasia esculenta. Nat Prod Res Chem. 2017; 5(3). 
14. Oktavianingsih L, Suharyanto E, Daryono BS, Purnomo P. Traditional usages of Taro (Colocasia spp.) by ethnic communities in Borneo. Biosaintifika: Journal of Biology and Biology Education. 2017; 9:248-56. https://doi.org/10.15294/biosaintifika.v9i2. 9956

15. Kaushal P, Kumar V, Sharma HK. Utilization of taro (Colocasia esculenta): A review. J Food Sci Technol. 2015; 52:27-40. https://doi.org/10.1007/s13197-0130933-y

16. Kumawat NS, Chaudhari SP, Wani NS, Deshmukh TA, Patil VR. Antidiabetic activity of ethanol extract of Colocasia esculenta leaves in alloxan induced diabetic rats. Int J Pharmtech Res. 2010; 2:1246-9.

17. Gonçalves RF, Silva AM, Silva AM, Valentão P, Ferreres F, Gil-Izquierdo A, et al. Influence of taro (Colocasia esculenta L. Shott) growth conditions on the phenolic composition and biological properties. Food Chem. 2013; 141:3480-5. https://doi.org/ 10.1016/j.foodchem.2013.06.009

18. Lee $S$, Najiah $M$, Wee $W$. In vitro antimicrobial activities of Colocasia esculenta extract against Vibrio spp.-short communication. Agricultura. 2010; 7:5-7.

19. Shahriar M, Tithi NA, Akhter R, Kamal S, Narjish SN, Bhuiyan MA. Phytochemical and pharmacological investigation of the crude extract of Typhonium trilobatum (L.) Schott World J Pharm Res. 2015; 4:167-88.

20. Banerjee S, Adak K, Adak MM, Ghosh S, Chatterjee A. Effect of some antinutritional factors on the bioavailability of minerals along with the study of chemical constituents \&antioxidant property in Typhonium trilobatum and Spinacia oleracea. Chem Sci Rev Lett. 2015; 4:429-39.

21. Lablab purpureus (hyacinth bean). [Cited 2019 Jul 08]. Available from: https://www.cabi.org/isc/ datasheet/30003

22. Al-Snafi, AE. The pharmacology and medical importance of Dolichos lablab (Lablab purpureus)A review. IOSR J Pharm. 2017; 7:22-30. https://doi. org/10.9790/3013-0702012230

23. Hossain S, Ahmed R, Bhowmick S, Al Mamun A, Hashimoto M. Proximate composition and fatty acid analysis of Lablab purpureus (L.) legume seed: Implicates to both protein and essential fatty acid supplementation. SpringerPlus. 2016; 5:1-10. https:// doi.org/10.1186/s40064-016-3587-1
24. Momin MA, Habib MR, Hasan MR, Nayeem J, Uddin N, Rana MS. Anti-inflammatory, antioxidant and cytotoxicity potential of ethanolic extract of two Bangladeshi Bean Lablab Purpureus (L.) sweet white and purple. Int J PharmSciRes. 2012; 3:776-81.

25. Satya S, Bal LM, Singhal P, Naik SN. Bamboo shoot processing: Food quality and safety aspect (a review). Trends Food Sci Tech. 2010; 21:181-9. https://doi. org/10.1016/j.tifs.2009.11.002

26. Govindan B, Johnson AJ, Nair SN, Gopakumar B, Mallampalli KSR,Venkataraman R, et al. Nutritional properties of the largest bamboo fruit Melocanna baccifera and its ecological significance. Sci Rep. 2016; 6. https://doi.org/10.1038/srep26135

27. Das MC, Nath AJ, Das AK. Indigenous traditional knowledge in conservation and management of Bamboos of Barak valley, Assam. J Tradit. Folk Med. 2016; 2:185-92.

28. Manna K, Debnath B. Phytochemicals, nutritional properties and anti-oxidant activity in young shoots of Melocanna baccifera, a traditional vegetable of Northeast India. J Food Agric Environ. 2020; 18(1):7-13.

29. Thapa K, Poudel M, Adhikari P. Moringa oleifera: A review articleon nutritional properties and its prospect in the context of Nepal. ActaSci Agric. 2019; 3:47-54. https://doi.org/10.31080/ASAG.2019.03.0683

30. Elangovan M, Dhanarajan MS, Rajalakshmi A, Jayachitra A, Pardhasaradhi M, Narasimharao B. Analysis of phytochemicals, antibacterial and antioxidant activities of Moringa oleifera Lam. leaf extract-an in vitro study. Int J Drug Dev Res. 2014; 6:173-80.

31. Gopalakrishnan L, Doriya K, Kumar DS. Moringa oleifera: A review on nutritive importance and its medicinal application. Food Sci Hum Well. 2016; 5:49-56. https://doi.org/10.1016/j.fshw.2016.04.001

32. Jaiswal BS. Solanum torvum: A review of its traditional uses, phytochemistry and pharmacology. Int J Pharma Bio Sci. 2012; 3:104-11.

33. Akoto O, Borquaye LS, Howard AS, KonwurukN. Nutritional and mineral composition of the fruits of Solanum torvum from Ghana. Int J Food Sci Technol. 2015; 1:222-6.

34. Mukta N, Neeta PM. A Review on sesame-an ethno medicinally significant oil crop. Int J Life Sci Pharma Res. 2017; 7 (2):L58-63. 
35. Sesame seeds nutrition facts [Internet]. [Cited 2019 August 05]. Available from: https://www.nutritionand-you.com/sesame-seeds.html

36. Prasad MNN, Sanjay KR, Prasad DS, Vijay N, Kothari R, Swamy SN. A review on nutritional and nutraceutical properties of sesame. J Nut Food Sci. 2012; 2:2. https://doi.org/10.4172/21559600.1000127

37. Agati (Sesbania grandiflora) [Internet]. [Cited 2019 August 06]. Available from: https://www.feedipedia. org/node/254

38. Reji AF, Alphonse NR. Phytochemical study on Sesbania grandiflora. J Chem Pharm Res. 2013; 5:196-201.

39. Balamurugan S, Vijayakumar S, Prabhu S, Yabesh JM. Traditional plants used for the treatment of gynaecological disorders in Vedaranyam taluk, South India- An ethnomedicinal survey. J Tradit Complement Med. 2018; 8:308-23. https://doi. org/10.1016/j.jtcme.2017.06.009

40. Sesbania grandiflora - Agathi - Benefits, Nutrition [Internet]. [Cited 2019 August 06]. Available from: https://www.medhyaherbals.com/sesbaniagrandiflora/

41. All about Agathi (Sesbania grandiflora) [Internet]. [Cited 2019 Aug 07]. Available from: http:// theindianvegan.blogspot.com/2014/01/all-aboutagathi-sesbania-grandiflora.html

42. Kamisah Y, Othman F, Qodriyah HM, Jaarin V. Parkia speciosa hassk: A potential phytomedicine. Evid -Based Complementary Altern Med. 2013. https://doi.org/10.1155/2013/709028

43. Debnath B, Manna K. Phytochemicals and nutrient profiles, anti-oxidant activity study of three edible parts (Flower, Fruit and Stem) of Musa paradisiaca. CurrBiotechnol. 2019; 8(1). https://doi.org/10.2174/ 2211550108666190315161848

44. Onyenekwe PC, Okereke OE, Owolewa SO. Phytochemical screening and effect of Musa paradisiaca stem extrude on rat haematological parameters. Curr Res J Biol Sci. 2013; 5:26-9. https:// doi.org/10.19026/crjbs.5.5468

45. Imam MZ, Akter S. Musa paradisiaca L. and Musa sapientum L. A phytochemical and pharmacological review. J ApplPharm.Sci. 2011; 1:14-20.

46. Bananas 101: Nutrition Facts and Health Benefits [Internet]. [Cited2019 August 19].Available from: https://www.healthline.com/nutrition/foods/ bananas

47. Calories in raw banana stem [Internet]. [Cited 2019 Jul 14].Available from: https://www.myfitnesspal. com/food/calories/raw-banana-stem-392353092

48. Health benefit of banana flower [Internet]. [Cited 2019 Jul 04]. Available from: https://www. healthbenefitstimes.com/health-benefits-of-bananaflower/

49. Toyin YM, OlakunleAT, Adewunmi A.M. 15toxicity and beneficial effects of some african plants on the reproductive system. Toxicological Survey of African Medicinal Plants; 2014. p. 445-92. https:// doi.org/10.1016/B978-0-12-800018-2.00015-7

50. Praveena JD,Estherlydia D. Comparative study of phytochemical screening and antioxidant capacities of vinegar made from peel and fruit of pineapple (Ananas comosus L.). Int J Pharma Bio Sci. 2014; 5:394-403.

51. Hassan A, Othman Z, Siriphanich J. 10 Pineapple (Ananas comosus L. Merr.). Postharvest Biology and Technology of Tropical and Subtropical Fruits; 2011. p. 194-218. https://doi. org/10.1533/9780857092618.194

52. Sopie E, Tanoh H, Kouakou L, Yatty J, Kouamé P, Mérillon J. Phenolic profiles of pineapple fruits (Ananas comosus L. Merrill) Influence of the origin of suckers. Aust J Basic and Appl Sci. 2011; 5:1372-8.

53. Sun GM, Zhang XM, Soler A, Marie-Alphonsine PA. Marie-Alphonsine. Nutritional composition of pineapple (Ananas comosus (L.) Merr.). Nutritional Composition of Fruit Cultivars; 2016.p. 609-37. https://doi.org/10.1016/B978-0-12-4081178.00025-8

54. Emmanuel MM, Didier DS. Traditional knowledge on medicinal plants use by ethnic communities in Douala, Cameroon. Eur J Med Plant. 2012; 2:159. https://doi.org/10.9734/EJMP/2012/878

55. Pineapple nutrition facts [Internet]. [Cited 2019 August 04]. Available from: https://www.nutritionand-you.com/pineapple.html

56. Lawal D. Medicinal, pharmacological and phytochemical potentials of Annona comosus Linn. Peel - A review. BAJOPAS. 2013; 6:101-104. https:// doi.org/10.4314/bajopas.v6i1.21

57. Ranasinghe RASN, Maduwanthi SDT, Marapana RAUJ. Nutritional and health benefits of Jackfruit 
(Artocarpus heterophyllus Lam.): A Review. Int J Food Sci. 2019. https://doi.org/10.1155/2019/4327183

58. Jackfruit nutrition facts [Internet]. [Cited 2019 August 04]. Available from: https://www.nutritionand-you.com/jackfruit.html

59. Nutrition in boiled jackfruit seeds [Internet]. [Cited 2019 August 05]. Available from: https://www. livestrong.com/article/546837-nutrition-in-boiledjackfruit-seeds/

60. Swami SB, Thakor NJ, Haldankar PM, Kalse SB. Jackfruit and its many functional components as related to human health: A review. Compr Rev Food Sci F. 2012; 11:565-76. https://doi.org/10.1111/ j.1541-4337.2012.00210.x

61. Diospyros malabarica- (Desr.) Kostel [Internet]. [Cited 2019 August 07]. Available from: https://pfaf. org/user/Plant.aspx?LatinName=Diospyros + malaba rica

62. Kaushik V, Saini V, Pandurangan A, Khosa RL, Parcha V. A review of Phytochemical and biological studies of Diospyros malabarica. Int J Appl Pharm Sci. 2013; 2:167-9.

63. Sajib MA, Jahan S, Islam MZ, Khan TA, Saha BK. Nutritional evaluation and heavy metals content of selected tropical fruits in Bangladesh. Int Food Res J. 2014; 21:609-15.

64. Chavan SS, Shamkuwar PB, Damale MG, Pawar DP. A comprehensive review on Annona reticulata. Int JPharm SciRes. 2014; 5:45.

65. Chen J, Chen Y, Li X. Beneficial aspects of custard apple (Annonasquamosa L.) seeds. 2011; 439-45. https://doi.org/10.1016/B978-0-12-375688-6.10052-0

66. Annona squamosa (sugar apple) [Internet]. [Cited 2019 August 08]. Available from: https://www.cabi. org/isc/datasheet $/ 5820$

67. Biba VS, Lakshmi S, Dhanya GS, Remani P. Phytochemical analysis of Annona squamosa seed extracts. Int J Appl Pharm Sci Res. 2013; 3:29-31.

68. Ma C, Chen Y, Chen J, Li X, Chen Y. A Review on Annona squamosa L.: Phytochemicals and biological activities. Am J Chin Med. 2017; 45:933-64. https:// doi.org/10.1142/S0192415X17500501

69. Bhardwaj A, Satpathy G, Gupta PK. Preliminary screening of nutraceutical potential of Annona squamosa, an underutilized exotic fruit of India and its use as a valuable source in functional foods. J Pharmacogn Phytochem. 2014; 3:172-80.
70. Sugar-apples, (sweetsop), raw [Internet]. [Cited 2019 August 08]. Available from: https://nutritiondata. self.com/facts/fruits-and-fruit-juices/2069/2

71. Jujube [Internet]. [Cited 2019 August 09]. Available from: https://en.wikipedia.org/wiki/Jujube

72. Gao QH, Wu CS, Wang M. The jujube (Ziziphus jujuba Mill.) fruit: A review of current knowledge of fruit composition and health benefits. J Agric Food Chem. 2013; 61:3351-63. https://doi.org/10.1021/ jf4007032

73. Ghobadi A, Amini-Behbahani F, Yousefi A, Shirazi MT, Behnoud N. Medicinal and nutritional properties of Ziziphus jujube mill. in traditional Persian medicine and modern phytotherapy. Crescent J Medical Biol Sci. 2019; 6:146-50.

74. Vijaylakshmi P, Radha R. An overview: Citrus maxima. J Phytopharmacol. 2015; 4:263-7.

75. Pomelo [Internet]. Available from: https://en.wiki pedia.org/wiki/Pomelo.

76. Debnath B, Singh WS, Manna K. A phytopharma cological review on Ananas comosus. AdvTradit Med (ADTM). 2021. https://doi.org/10.1007/s13596-02100563-W

77. Saxena P, Panjwani D. Cardioprotective potential of hydro-alcoholic fruit extract of Ananas comosus against isoproterenol induced myocardial infraction in Wistar Albino rats. J Acute Dis. 2014; 3:228-34. https://doi.org/10.1016/S2221-6189(14)60051-2

78. Ali K, Ashraf A, Biswas, NN. Analgesic, antiinflammatory and antidiarrheal activities of ethanolic leaf extract of Typhonium trilobatum L. Schott. Asian Pac J Trop Biomed.2012; 2:722-6. https://doi. org/10.1016/S2221-1691(12)60217-2

79. Lobo VC, Phatak A, Chandra N. Acute toxicity studies of some Indian medicinal plants. Pharmacogn Journal. 2010; 2(8):207-10. https://doi.org/10.1016/ S0975-3575(10)80094-X

80. Debnath B, Manna K. Phytochemicals and nutrient profiles, anti-oxidant activity study of three edible parts (flower, fruit and stem) of Musa paradisiaca. CurrBiotechnol. 2019; 8(1):32-41. https://doi.org/10. 2174/2211550108666190315161848

81. Mujeeb F, Bajpai P, Pathak N. Phytochemical evaluation, antimicrobial activity, and determination of bioactive components from leaves of Aegle marmelos. Bio Med Res Int. 2014;2014. https://doi. org/10.1155/2014/497606 
82. Harinarayan CV, Akhila H. Modern India and the tale of twin nutrient deficiency-calcium and vitamin D-nutrition trend data 50 Years-retrospect, introspect, and prospect. Front Endocrinol. 2019; 10:493. https://doi.org/10.3389/fendo.2019.00493

83. Agrahar-Murugkar D, Pal PP. Intake of nutrients and food sources of nutrients among the Khasi tribal women of India. Nutrition. 2004; 20(3):268-73. https://doi.org/10.1016/j.nut.2003.11.008
84. Shimelis EA, Rakshit SK. Proximate composition and physico-chemical properties of improved dry bean (Phaseolus vulgaris L.) varieties grown in Ethiopia. LWT-Food Sci. Technol. 2005; 38(4):331-8. https:// doi.org/10.1016/j.lwt.2004.07.002

85. Kunwar RM, Mahat L, Acharya RP, Bussmann RW. Medicinal plants, traditional medicine, markets and management in far-west Nepal. J Ethnobiol Ethnomedicine. 2013; 9(1):1. https://doi. org/10.1186/1746-4269-9-24 